\title{
User Demand Potentials of Bike in Sebelas Maret University Surakarta
}

\author{
Dewi Handayani ${ }^{1}$, Amirotul $\mathrm{MHM}^{2}$, Belviana Dyas Tamarani ${ }^{3}$ \\ \{dewi@ft.uns.ac.id ${ }^{1}$, amirotulmhm@staff.uns.ac.id ${ }^{2}$, abeldyast@gmail.com ${ }^{3}$ \} \\ Civil Engineering Study Program, Faculty of Engineering, Sebelas Maret University Surakarta ${ }^{123}$
}

\begin{abstract}
As one of the university which applies Green Campus in Indonesia, Sebelas Maret University Surakarta keeps on developing the management of an eco friendly campus. In a bid to decrease the impact of environment polution, UNS is planning to add free bike as transportation for their students and academic staffs in campus. This research is aimed to find the probability of user demand of free bike. The data was collected by interviews with the variables are waiting time, travel time, and the bike comfortness. It is found that the best scenario for choosing bike as a media transportation $(90,37 \%)$ is when waiting time of bus campus is long (more than 22 minutes), bus travel time is normal and cycling comfort is good. Waiting time, travel time, and cycling comfort condition are variables that have a big influence on probability of potential demand.
\end{abstract}

Keywords: free bike, user demand, potential demand.

\section{Introduction}

As a supportive facility, the existence of modern transportation makes accessibility and mobility easy and possible for humans. As the era moves forward, the number of motor vehicle increases as well. Traffic jam, air pollution, high number of accidents, and long queues, are impact of development on transportation development impact. To overcome such issues, Green Transportation needed to be apply in more serious way. Green Transportation is the concept of eco friendly transportation which is developed to minimize the impact of fossil fuels to the environment and application of it would help overcome some of these issues caused by development in transportation. Wind Bike is one of the media forms of Green Transportation. As one of Indonesian University which applies Green Trasnportation, Sebelas Maret University Surakarta (UNS) keeps on developing the management of eco environment campus. To decrease the impact of air pollution, UNS is planning to add free transportation for their students and academic staffs in campus by providing bike. Bike is chosen as the alternative media transportation in campus to curb pollution.

Stated Preference is a method which uses the response on preferences of media transportation to estimate its utilization function [1]. The basic principle of Stated Preference is its ability to provide choices of scenario, then guide the respondent to choose as they please. The main goal is to determine the relative impacts of each attributes on the satisfaction of each individual and their choices. The utilization which is calculated using Stated Preference is

ICCSET 2018, October 25-26, Kudus, Indonesia

Copyright (C) 2018 EAI

DOI 10.4108/eai.24-10-2018.2280496 
described as Indirect Utility. Utility could be referred to as a linear combination from some attributes and variables in the form of:

$\mathrm{U}_{\mathrm{n}}=\mathrm{a}_{0}+\mathrm{a}_{1} \mathrm{x}_{1}+\ldots+\mathrm{a}_{\mathrm{n}} \mathrm{x}_{\mathrm{n}}$

Un is choices of utility,

$\alpha_{0}, . ., \alpha_{\mathrm{n}}=$ coefficient

$x_{0}, . ., x_{\mathrm{n}}=$ variable

According to Tamin [2], logit binomial model depends on assumptions that random components distributes independently, distributes identically and follows Gumbell distribution. In the equation, it shows that the probability of a person to choose either bike or bus is the function of the utility difference of both choices. Simply put, the function of the utility itself which moves linearly which consists of various attributes. Therefore, the utility difference from both choices is stated in the form of attribute difference. So the equation is as follow:

$$
U_{s p}-U_{b k}=a_{0}+a_{1}\left(X_{1}^{t-n t}\right)+a_{2}\left(X_{2}^{t-n t}\right)+\ldots \ldots \ldots . .+a_{n}\left(X_{n}\right)
$$

This research has the same topic on media transportation which uses the Stated preference method shares the same method as the research done by Lulut Indriyaningrum (2012)[3], Selviana Walsen (2012)[4], Dyaning Wahyu (2013)[5], dan Yoga Pranata (2015)[6]. Data analysis using binary logit model used in this study has similarities with Selviana Walsen (2012) [4], Dyaning Wahyu Primasari (2013) [5], and Handayani (2017) [7]. What differentiates this research from the previous researches is the attribute of the Stated Preference questionaire which includes the waiting time, travel time, and comfortness of the bike, analyzed using the logit binomial model.

\section{Method}

The research took place in Sebelas Maret University Surakarta (UNS) Campus. In Ir. Sutami Street 36A, Kentingan, Jebres, Surakarta, Central Java. The number of samples is measured by the possible number of bike users in Sebelas Maret University. The sample will be collected by the questionnaire method. Questionnaires are given to each faculties in Sebelas Maret University, the sample determination is from population with 5\% error level [8] and it got the respond from 379 responses. 


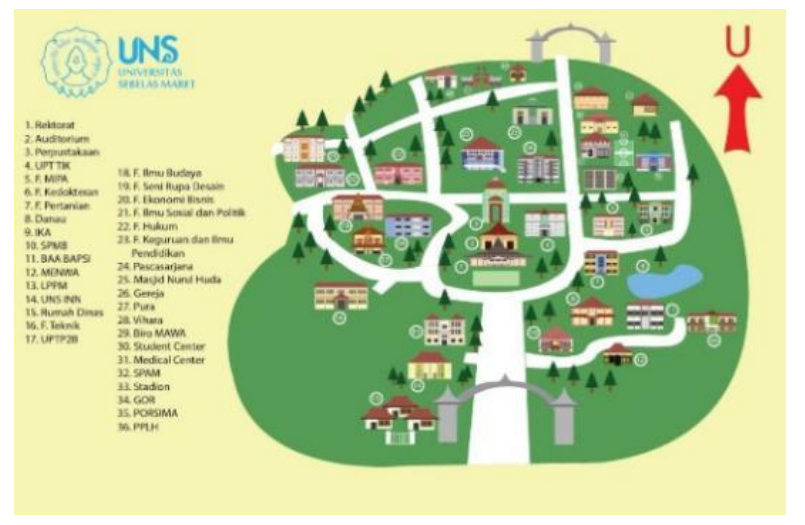

Fig. 1. Research Location.

In this research, the three attributes are examined. Lhe level of campus bus attributes based on the existing condition, and the level of wind bike attributes based on the preliminary plan. Table 1, it is provided the magnitude of each level of the attribute. Combination of existing condition of campus bus and preliminary plan of wind bike, Table 2 , it is provided the scenario to build the questionnaire form.

Table 1. Attribute and level.

\begin{tabular}{|c|c|c|c|c|c|c|}
\hline \multirow[t]{2}{*}{ Moda } & \multicolumn{2}{|c|}{$\begin{array}{c}\text { Attribute } 1 \\
\text { (Waiting time, mins) }\end{array}$} & \multicolumn{2}{|c|}{$\begin{array}{c}\text { Attribute } 2 \\
\text { (Travel time, mins) }\end{array}$} & \multicolumn{2}{|c|}{ Attribute 3 (Comfort) } \\
\hline & Normal & Long & Normal & Long & Comfort & Less Comfort \\
\hline $\begin{array}{l}\text { Campus } \\
\text { Bus }\end{array}$ & 13 & 22 & 5 & 5 & $\begin{array}{l}\text { Can carry } \\
\text { many things } \\
\text { and } \\
\text { comfortable } \\
\text { seat }\end{array}$ & - \\
\hline $\begin{array}{l}\text { Wind } \\
\text { Bike }\end{array}$ & 0 & 0 & 5 & 7.5 & $\begin{array}{l}\text { Providing basket } \\
\text { on bike and } \\
\text { comfortable } \\
\text { saddle }\end{array}$ & $\begin{array}{l}\text { Do not } \\
\text { providing basket } \\
\text { on bike and un } \\
\text { comfortable seat }\end{array}$ \\
\hline
\end{tabular}

Table 2. Research Scenario.

\begin{tabular}{cccc}
\hline Scenario & Attribute 1 & Attribute 2 & Attribute 3 \\
\hline 1 & Normal & Normal & Comfortable \\
2 & Normal & Normal & Less Comfortable \\
3 & Normal & Slow & Less Comfortable \\
4 & Long & Slow & Less Comfortable \\
5 & Long & Normal & Less Comfortable \\
6 & Long & Normal & Comfortable \\
\hline
\end{tabular}




\begin{tabular}{lcll}
\hline 7 & Long & Slow & Comfortable \\
8 & Normal & Slow & Comfortable \\
\hline
\end{tabular}

\section{Result and Discussion}

\subsection{Respondent Characteristic}

According to the compilation from the 379 respondents, the users characteristics determined by their gender has 103 male at $27 \%$ and 276 female at $73 \%$. The characteristics according to their age is calculated in percentage form.the bike user characteristics based on their age: 48 people (13\%) are 18 years old, 101 people (26\%) are 19, 103 people (27\%) are 20, 74 people $(20 \%)$ are 21,33 people $(9 \%)$ are 22 , and 20 people (5\%) are more than 22 years old.

Results based on their faculties could be seen in table 3, responses from the Faculty of Teacher Training and Education is 26\%, Faculty of Agriculture is $12 \%$, Faculty of Economic and Business is $11 \%$, Faculty of Social and Political Science is $10 \%$, Faculty of Engineering is $10 \%$, Faculty of Mathematics and Natural Science is $8 \%$, Faculty of Medicine is $7 \%$, Faculty of Humanities and Faculty of Law are $6 \%$ and Faculty of Arts and Design is $4 \%$.

Table 3. Number of respondents according to their faculties.

\begin{tabular}{lcc}
\hline \multicolumn{1}{c}{ Faculty } & Total & Percentage \\
\hline Faculty of Engineering & 36 & $10 \%$ \\
Faculty of Humanities & 24 & $6 \%$ \\
Faculty of Arts and Design & 13 & $4 \%$ \\
Faculty of Law & 24 & $6 \%$ \\
Faculty of Economic and Business & 40 & $11 \%$ \\
Faculty of Social and Political Science & 38 & $10 \%$ \\
Faculty of Agriculture & 47 & $12 \%$ \\
Faculty of Medicine & 28 & $7 \%$ \\
Faculty of Mathematics and Natural Science & 30 & $8 \%$ \\
Faculty of Teacher Training and Education & 99 & $26 \%$ \\
Total & 379 & $100 \%$ \\
\hline
\end{tabular}

Source: Primary Data Analysis (2018)

\subsection{Moda Choice Model}

This research is stated in 8 scenarios. Equation for logit binomial model of choosing the models between bike and campus bus could be formulated. The model is gained by compiling the choosing of moda probabilities which are chosen by the respondents and presented in the table as in the previous sub chapter. Calculation by multiple linear regression analysis is gained from transforming equations of the differences of logit binomial model. Double regression analysis was done with the help of Ms. Excel and SPPS 18. 


\subsubsection{Utility function}

From the result of calculation, the estimated values of its regression coefficient model could be gained, so the utility model is as follows:

$\mathrm{U}_{\mathrm{sp}-\mathrm{bk}}=0,722-0,069\left(\mathrm{~W}_{\mathrm{sp}}-\mathrm{W}_{\mathrm{bk}}\right)-0,140\left(\mathrm{~T}_{\mathrm{sp}}-\mathrm{T}_{\mathrm{bk}}\right)+1,089\left(\mathrm{C}_{\mathrm{sp}-}-\mathrm{C}_{\mathrm{bk}}\right)$

\subsubsection{Logit Binomial Model}

In model analysis using logit binomial, according to the previous analyzed data which came from the difference in utility between bike and shuttle bus the bike choosing probability could be calculated as:

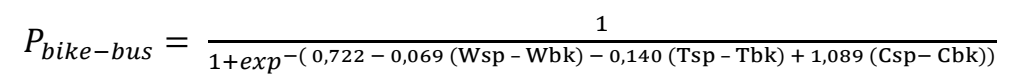

$\begin{array}{ll}\text { By, } & \\ \mathrm{P}_{\text {bike-bus }} & =\text { Probability of choosing bike } \\ \mathrm{W}_{\mathrm{sp}} & \text { = Waiting time of the bike } \\ \mathrm{W}_{\mathrm{bk}} & \text { = Waiting time of the shuttle bus } \\ \mathrm{T}_{\mathrm{sp}} & =\text { Travel time of the bike } \\ \mathrm{T}_{\mathrm{bk}} & =\text { Travel time of the shuttle bus } \\ \mathrm{C}_{\mathrm{sp}} & \text { = Comfort of the bike } \\ \mathrm{C}_{\mathrm{bk}} & \text { = Comfort of the shuttle bus }\end{array}$

On Table 4, the probability of choosing wind bike is presented

Table 4. Probability of choosing wind bike for each scenario

\begin{tabular}{cccccc}
\hline Scenario & Waiting Time & Travel Time & Comfort & Utilities & Probability (P) \\
\hline 1 & -13 & 0 & 0 & 1.619 & $83.4657 \%$ \\
\hline 2 & -13 & 2.5 & 0 & 1.269 & $78.0572 \%$ \\
\hline 3 & -13 & 2.5 & -1.6384 & -0.51522 & $37.3971 \%$ \\
\hline 4 & -13 & 0 & -1.6384 & -0.16522 & $45.8789 \%$ \\
\hline 5 & -22 & 0 & 0 & 2.24 & $90.3784 \%$ \\
\hline 6 & -22 & 2.5 & 0 & 1.89 & $86.8756 \%$ \\
\hline 7 & -22 & 0 & -1.6384 & 0.455782 & $61.2013 \%$ \\
\hline 8 & -22 & 2.5 & -1.6384 & 0.105782 & $52.6421 \%$ \\
\hline
\end{tabular}

\subsubsection{Model Sensitivity Analysis}


To find out whether the model is well produced, sensitivity testing of the model gained is needed. This is done due to factors of some variables so that the probability of model choosing could be gained. This testing is done to waiting time, travel time, and comfort variables.

The first scenario in this analysis shows that the waiting time and travel time of the bus is normal, while the comfort of the bike is good. The probability of this happening is $83.46 \%$. The switching threshold point of model choosing (probability 50\%) is when the bike travel time is 16 minutes 36 seconds. If the bike travel time is less than the estimated time, the probability of students choosing it as an alternative transportation in campus is high. On the contrary, if the bike travel time is more than the estimated time, the students would probably choose the campus bus.

Second scenario in this analysis shows that the waiting time of the bus is normal, while the travel time of the bike is long but the comfort of bike is good. The probability of this happening is $78.05 \%$. The switching threshold point of model choosing (probability $50 \%$ ) is when the bike waiting time is 16 minutes 48 seconds. If the bike waiting time is less than the estimated time, the probability of students choosing bike as an alternative transportation in campus is high and if the bike waiting time is more than 16 minutes 48 seconds, the students would probably choose the campus bus.

Third scenario shows that the waiting and travel time of bus is normal, the travel time of bus is normal, and the comfort of the bike is not good. The probability of this happening is $37.39 \%$. The switching threshold point of model choosing (probability 50\%) is when the bike travel time is 3 minutes 48 seconds. If the bike travel time is less than estimated time, the probability of students choosing bike as an alternative transportation in campus is high and if the bike travel time is more than 3 minutes 48 seconds, the students would probably choose the campus bus.

Fourth scenario in this analysis is that the waiting time of the bus is normal, the travel time of the bike is normal, and the comfort of the bike is not good. The probability of this happening is $45.87 \%$. The switching threshold point of model choosing (probability $50 \%$ ) is when the bike waiting time is 5 minutes 30 seconds. If the bike waiting time is less, the probability of students choosing bike as an alternative transportation in campus is high and if the bike waiting time is more than 5 minutes 30 seconds, the students would probably choose the campus bus.

Fifth scenario in this analysis is that the waiting time of the bus is long, the travel time of the bike is normal, and the comfort of the bike is good. The probability of this happening is $90.37 \%$. The switching threshold point of model choosing (probability 50\%) is when the bike waiting time is 27 minutes 18 seconds. If the bike waiting time is less, the probability of students choosing bike as an alternative transportation on campus is high and if the bike waiting time is more than 27 minutes 18 seconds, the students would probably choose the campus bus.

Sixth scenario in this analysis is that the waiting time of the bus is long, the travel time of the bus is normal, and the comfort of the bike is good. The probability of this happening is $86.87 \%$. The switching threshold point of model choosing (probability $50 \%$ ) is when the bike travel time is 21 minutes. If the bike travel time is less than 21 minutes, so the probability of students choosing bike as an alternative transportation in campus is high and. On contrary, if 
the bike travel time is more than 21 minutes, the students would probably choose the campus bus.

Seventh scenario is that the waiting time of the bus is long, the travel time of the bus is normal, and the comfort of the bike is good. The probability of this happening is $86.87 \%$. The switching threshold point of model choosing (probability 50\%) is when the bike travel time is 21 minutes. If the bike travel time is less than 21 minutes, the probability of students choosing bike as an alternative transportation in campus is high and if the bike travel time is more than 21 minutes, the students would probably choose the campus bus.

Last scenario in this analysis is that the waiting time of the bus is long, the travel time of the bike is long, and the comfort of the bike is not good. The probability of this happening is $52.64 \%$. The switching threshold point of model choosing (probability 50\%) is when the bike waiting time is 13 minutes 12 seconds. If the bike waiting time is less than 13 minutes 12 seconds, so the probability of the students choosing a bike as an alternative transportation in campus is high. On contrary, if the bike waiting time is more than 13 minutes 12 seconds, the students would probably choose the campus bus.

The above scenario works with the accuracy of 54\%, which means only $54 \%$ from the free variables which can present the bike in campus model choosing. We could assume that the highest probability happened at the fifth scenario with $90.37 \%$ with the condition of the bus waiting time been long, the bike travel time is normal, and the comfort of the bike is good. From the discussion above, we could also see that the lowest probability that happened is in the third scenario with $37.39 \%$, with the conditions of the bus waiting and travel time been normal, and the comfort of bike is not good. The best condition for the next implementation however is when the bike waiting time is in 0 minutes or there is no waiting time for the bike and it is in perfect condition with at least a basket on it and a comfortable saddle.

\section{Conclusion}

Potential of demand from the probability of $37.39 \%$ (scenario waiting time of bus is normal (13 minutes), bus travel time is normal (5 minutes) and cycling comfort is not good), to the probability of $90.37 \%$ (scenario waiting time of bus is long (22 minutes), bus travel time is normal (5 minutes) and cycling comfort is good). The accuracy level of demand probability potential is 54\%. Therefore, waiting time, travel time, and cycling comfort condition are variables that have a big influence on probability of potential demand.

\section{Recommendation}

According to this research, we could then draw out some suggestions which would include:

1) There are three attributes is used in this research which are, the travel time, waiting time, and comfort. For the further research, the researcher suggests that there are other attributes which could be included such as security, cost, or others which influence the model choosing. 
2) For the policy makers of campus bike implementation, the bike is chosen when it's in the best condition, when there is no bike waiting time or the waiting time is equal to 0 minutes, and when the comfort of the bike is good with a basket on bike and a comfortable saddle provided.

\section{References}

[1] D. A. Hensher, "Stated preference analysis of travel choice: the state of practice, Trasportation 21," pp. 107-133, 1994.

[2] O. . Tamin, Perencanaan dan Pemodelan Transportasi Jilid I. ITB Bandung, 2000.

[3] A. Indriyaningrum, L., Narendra, A., "Analisis Pola Permintaan Sepeda Kampus Bagi Mahasiswa Universitas Negeri Semarang,” J. Univ. Negeri Semarang. Semarang, 2012.

[4] S. Walsen, "Pemodelan Penggunaan Sepeda Di Dalam Kampus Universitas Brawijaya Malang," J. Teknol., pp. 1002-1011, 2012.

[5] A. D. Primasari, D. W., Ernawati, J. and W, "Pemilihan Moda Transportasi ke Kampus oleh Mahasiswa Universitas Brawijaya," 2013, p. 84-93.

[6] Y. K. Pranata, Y. and Setyawan, "Kajian Penyediaan Lajur Sepeda Di Lingkungan Universitas Brawijaya," 2015.

[7] M. A. Handayani D, Putri H.C., “, Logit and probit model in toll sensitivity analysis of SoloNgawi, Kartosuro-Palang Joglo segment based on Willingnes to pay (WTP)," IOP Conf. Ser. Earth Environ. Sci., 2017.

[8] Sugiyono, "Statistik untuk penelitian, Penerbit Alfabeta." Bandung, 2013. 